INDIVIDUAL CONTRACTS, COLLECTIVE BARGAINING AND TRADE UNIONISM: A CASE FOR THE UNION VOICE

Alan Tuckman

$\&$

Chris Finnerty 
Address for all correspondence:

Dr. Alan Tuckman

Nottingham Business School

Burton Street

Nottingham

NG1 4BU

Autobiographical Note:

Alan Tuckman has a BA and PhD from the University of Hull, and is a Senior Lecturer in the Department of Human Resource Management at Nottingham Business School.

Chris Finnerty has an MA in HRM from Nottingham Business School, is a Regional Officer with a Trade Union and serves as an Industrial Tribunal member. 
Abstract:

-3 - 


\section{A Case for the Union Voice: Individual Contracts, Collective Bargaining And Trade}

\section{Unionism.}

\section{$\underline{\text { Introduction }}$}

The emergence of HRM has emphasized an individualization of the employment relationship which replaces established pay scales and conditions with performance related pay and individual contracts of employment. In this agenda HRM practitioners have precipitated the 'exclusion' [1, 2] of trade unions in a shift in the 'frontier of control' [3]. This has invited unilateral management prerogative encouraged by economic circumstances and government ideology and practice. The outcome is witnessed in the simultaneous decline in organized labour and in collective bargaining. A new indicator, that of trade union de-recognition, has emerged to replace that of the strike to reflect the current state of activity, if not the balance of power, in the employment relationship.

Despite not including legislation for its first year of office the Labour Government has committed itself to entitlement to trade union recognition. In pre-election documents it proposed that:

Where a majority of the relevant the relevant workforce vote to be represented by a trade union, there should be a legal obligation on employers to recognise a union for collective bargaining on issues of pay, hours and holidays, and training. The bargaining agenda could be extended to other issues by mutual agreement. ${ }^{1}$

This proposal reflects discussion between the Labour Party and unions, with the aspirations of the TUC presented in the report from their Task Force Your Voice at Work presented to the 1995 Congress [5]. As well as the progressive distancing of the Labour Party from the policies and aspirations of the trade unions - although they took early action to reverse the derecognition of unions at GCHQ - the reason for the delay in implementing more general legislation appears to be the fundamental details of such proposals. Before debate moves to these technical details, important as they are - the problems of defining the role of the formal agencies, of appropriate bargaining units, and the possible sanctions against intransigent employers - we wish to address the more fundamental issue of the 'voice' for employees within the workplace. 
In reflecting on the implications of recognition we concur with a concluding observation made by

Wood, in a recent report produced for the Institute of Personnel and Development, that:

As we take the issue into the broader fields of industrial relations it becomes increasingly obvious that the uncertainties in the statutory recognition debate extend well beyond narrow legal and political concerns. They expose how much we still need to know about employees' attitudes towards both unions and other non-union channels of involvement; how little we know about managements' attitudes towards unions and industrial relations in general; and how we need to understand more about the relationship between collective bargaining and other forms of involvement, in theory and in practice. [6 p 34-5]

While we support an enhancement of formal collective relations between employers and trade unions we do not sanction an uncritical return to the traditional form, less the substance, of ritualized collective bargaining. Drawing from a survey of trade union members who have experienced a move from collective bargaining to personal contracts, which we report here, we find elements which can be supported in new forms of pay and contract determination. What is missing in many of the new arrangements - by definition in cases where this is accompanied by derecognition - is the support of trade unions in collective determination of pay levels, in formulation of procedures, and support of members grievances.

In making a case for a new collective relationship, in which trade unions return to a central role, we shall first examine the nature and extent of derecognition in Britain since the mid 1980s. We then move to a critique of collective bargaining as a means of pay determination and the alternative forms of individualized contract drawing on a recent agreement for 'single status' within the public sector. We then draw on evidence drawn from a survey of trade unionists who have remained in membership despite moving to personal contracts. Drawing this together we propose the re-framing of collective relations which encourages what we see as the more positive contributions to flexible employment practices encouraged by Human Resource Management.

\section{Derecognition, Union Exclusion and HRM}

Since the mid 1980s the emergence of a particularly British variation of HRM has increasingly marginalised trade unions, with the state and employers excluding them from collective relations 
$[1,2]$. In the process trade union concern has moved from how new management mechanisms - such as quality circles [7] - might introduce direct communication which bye passes collective bargaining to individual contracts and performance related pay that challenges their very recognition for collective bargaining purposes ${ }^{2}$. While the measure of strikes might have been the key indicator in traditional industrial relations - however imprecise - increasingly we might turn to some calculation of derecognition although, just as protracted debates on strike statistics suggested, we claim later are also understated. Collating the number of derecognitions does not have the authority of Employment Gazette although some measure of its extent is ascertained from a number of surveys [9-12]. The most recent, carried out by Gall and McKay [11] for Labour Research, identify 470 cases of derecognition between August 1988 and March 1996 based on notification by trade unions. These derecognitions are not evenly spread either temporally or by industrial sector. Early derecognitions where concentrated within printing and publishing, in provincial newspapers, and in a few other limited sectors. Recent instances show a spreading to almost all sectors particularly those effected by privatization including the public utilities the main employer of union members in our survey. The largest number of early derecognitions were amongst white collar workers, justified in part by management as the result of declining trade union membership. The effect is often a 'salami slicing' of sections of employees within an establishment, starting with white collar workers, until those covered by collective agreement constitute a small minority. Claydon [9], in the first major analysis of derecognition, noted the symptoms of this phenomena and differentiated between the depth of derecognition - the range of issues taken out of collective bargaining , and the breadth of derecognition - the groups of workers within an establishment no longer covered by collective agreement. In the time since Claydon's original study the coverage of collective bargaining has narrowed with derecognition pronounced amongst manual workers, with increasing numbers moving to personal contracts, most importantly amongst the previously highly organised workers in the chemical industry.

To some extent the pattern of derecognition might be seen as the reversal of some interrelated post-war trends. The growing public sector facilitated the incorporation of large sectors into collective bargaining while generally a growth in trade union membership amongst white collar workers masked long term decline - because of industrial decline - amongst more traditional 
manual workers [see e.g. 13]. However recent derecognition, particularly that at BP, has cut into the heartland of traditional trade union membership on sites where collective bargaining constituted the main communication between management and the workforce ${ }^{3}$. The derecognition at BP Chemicals, Baglan Bay in 1992, was integral to a phase of company wide job losses resulting from a benchmarking exercise. Workers at the site were refusing to sign new contracts for 'single status' did so at the threat to their jobs. However, later derecognition at Hull - in a pattern followed later at Grangemouth - and just as the TGWU were arguing to the House of Commons Employment Committee on the Baglan Bay and other derecognitions in the chemicals sector that: "in all cases employees have been exposed to extreme pressure, often amounting to intimidation." [14: 196], the manual workforce at the Hull plant where accepting 'single status' - including the introduction of PRP and an end to collective bargaining - by a majority in a workplace ballot.

\section{Measuring Derecognition}

In identifying problems in interpreting the survey evidence, not least the TUC's own attempts to gloss their own interpretation of the Labour Research results by pointing to increased recognition of unions for collective bargaining [15], we feel that more detailed cases are needed to understand both the underlying trends in employment relations and the prospects for future policy of both government and trade unions. On one side this seemingly blinkered response to an emergent HRM, the rolling back of collective relations, from trade unions mirrored by the myopic disengagement from the merits of a pluralist approach to collective representation by many managers.

Our research raises some immediate problems even for these survey results, indicating that the extent of this disengagement might be more extensive than this shows. It is apparent there are gaps in the information available for the Labour Research study based as it is on reports from trade unions. For example the total numbers of derecognition cases advised by the union which has been the subject of our research is shown as only two for the period 1988 to 1996 . Similarly the number of 
derecognition in the energy and water supply industry sectors - the main area in which the union operates - are indicated as six in the period 1994 to 1996 . The union now has some 2,000 members who have transferred onto personal contracts from collective bargaining mostly from 1990 to date. We also know from our survey that there are at least thirty companies that they work in, where derecognition has or is about to occur. Most of these thirty companies are known to be in the energy supply sector. Analysis of membership records show that taking account, not only the issue of personal contracts in the core businesses of the electricity supply companies but derecognitions arising from the disposal of non-core activities such as retail outlets and electrical contracting; it is more likely in our estimate that the union has been affected by derecognition in the period 1988 to 1996 not on two occasions as reported but by considerably more. If, however, the position is repeated in even a small number of other trade unions then the current situation regarding derecognition is much more widespread. Cumulative partial derecognition, represented by moves to personal contracts, going unnoticed as breadth widens within establishments. And depth of derecognition hiding the magnitude of change where formal representation agreements mask real marginalisation of trade union presence.

\section{The Hidden Derecognition}

Despite some managers, such as those at CoSteel in Sheerness [16], becoming evangelical about derecognition the issue is still a sensitive one - clearly for different reasons - for both management and unions. This hunch is reinforced by evidence from BP. In practice derecognition is of far longer standing with white collar unions losing collective bargaining in the mid 1980s, before the interest in the topic was spurred by some well publicised cases - that of GCHQ and at a Times newspapers' migration to Wapping. Management at BP, following negative reporting in the Financial Times (14th February 1992) of their derecognition at Baglan Bay, are vehement that these have not been derecognitions but argue that they have the introduced 'single status' with a continued recognition through Representation Agreements. 
Despite the Agreement being drafted unilaterally, and presented to the union as a fait accompli, it indicates some of the sensitivities if not contradictions of management's encroachment:

If any employee considers that he or she is suffering from unequal treatment on the grounds of sex, marital status, creed, colour, race or ethnic origins or trade union membership, he or she may make a complaint which will be dealt with through the agreed procedures. [17]

However at the centre of the changes and, because it covers a significant number of manual workers in a previous bastion of trade union organisation within such a major company, possibly the most significant move was the proposal that, with the end of collective bargaining:

Salaries are reviewed each year taking account of BP Chemicals ability to pay, the salary market, the site performance and the performance of individuals and teams.

Not only do personal contracts appear to have won more converts from among employers but they appear now to be more accepted by employees than trade unions would necessarily wish to admit. This may be a further explanation for the apparent shortcomings in the recording and reporting by trade unions of instances of derecognition. It could be that they fear it becomes a self fulfilling prophecy or that it is played down because it does not represent a cause of membership loss. Until a more complete picture of the true extent of derecognition can be painted it is small wonder that so few commentators appreciate the significance.

\section{The Problem of Collective Bargaining}

British Governments of all complexions, until the mid 1980s, have promoted collective bargaining as the most appropriate means of bringing consensus into industrial relations.

Within the voluntaristic British system - except within the public sector - the state could only prescribe the merits of collective bargaining to harmonise the employment relationship. Even when Flanders - the theorist of pluralism and collective bargaining - argued that management "can only regain control by sharing it" [18: p. 172] it was in the context of the lack of legitimacy amongst management in a period of full employment and relatively strong union organisation at workplace level. It was not until the early part of the 1980s with unprecedented levels of unemployment that this continuous support for collective bargaining came to a sudden halt. 
The clearest indication of a change in government attitude towards trade unions came about in 1984 - during the governments attack on the 'enemy within' of the miners union - when it was decided for supposed national security reasons to rid GCHQ in Cheltenham of trade union members. Already there was the indication that instrumentalism would be the bait for workers to withdraw from collective bargaining. GCHQ was a highly publicised dispute which undoubtedly began to legitimate the process of derecognition although the process was relatively slow to catch on, requiring the added impetus of the post - 1987 recession. Economic circumstances coalesced with employers realisation that, even with government encouragement, the frontier of control within, especially traditional, workplaces had not substantially shifted in their direction.

Despite the raft of employment legislation which had sought to contain industrial action by trade unions it was only at this stage that employers began to come out with their own assault on workplace relations although - as with the derecognition of white collar workers at BP - the pattern was already set. By 1992 the Secretary of State for Employment could argue that;

Traditional patterns of industrial relations, at least on collective bargaining and collective agreements, seem increasingly inappropriate and are in decline. ${ }^{4}$

It is not surprising then that some trade unions saw derecognition as part of a wider conspiracy certainly on the part of government and to a certain extent employers during this period which saw "a synergistic project to create a potent gradualist route to union exclusion" [1 p. 100]

But the roots of decline in collective bargaining are deeper than recent shift in government ideology and management strategy. Throughout the post war period Government attempts to manage conflicting demands of the economy and of social legitimacy, often fractured by industrial conflict, led to much of the period being characterised by pay policy and not free collective bargaining. Ironically one of the claims of the incoming Thatcher government in 1979 was to return to 'collective bargaining' - based on 'what employers could afford' - was to replace government pay policy with the 'free market' of collective bargaining. 
Within the context of high unemployment, decline in traditional industry, employees who survived the massive 'downsizing' where constrained by the trammels of collective bargaining particularly in the public sector where it was most secure - collective bargaining over pay had become at best ritualised at worst could be an intransigent confrontation between powerless unions and newly assertive managers. With a normal benchmark set by inflation and the cost of living - against what companies might afford - many must have felt that they where missing out on the levels of performance related pay indicated of the earning of some senior managers. But collective bargaining, and trade union membership, encompassed a range of other activities within the employment relationship. Trade union membership gave both representation and protection and, especially importantly for manual workers, made an important contribution to health and safety at work ${ }^{5}$.

\section{$\underline{\text { Single Status }}$}

With the furtherance of harmonious industrial relations through collective bargaining abandoned by central government, it remained the norm within local government employment. Given the overwhelming Labour control of local authorities recent proposals for 'single status' agreed by the National Joint Council for both APT\&C and Manual workers on $10^{\text {th }}$ March 1997 involving the three main unions and the employers appears an appropriate indicator of the future of collective bargaining under a Labour Government. Characterised by the unions as:

a modern and effective agreement which will meet the needs of local government and its employees into the $21^{\text {st }}$ century. [20, p. 3]

The agreement merges the previous manual and APT\&C grades into one pay scale, as well as introducing uniform conditions across local government employment. Each job or group of jobs will be subject to evaluation with local agreement placing it on the national pay scale.

Such a fundamental change in the employment relationship on this scale raises two important issues for our argument. Firstly it might be seen as an indicator of the willingness of trade unions to enter into such a move towards greater flexibility. Such a shift is apparent in the debate which has occurred within trade unions moving from opposition to a critical engagement with HRM [see e.g. 21, 22]. It was BP Chemicals ambition to introduce such flexibility, replacing the existing 
divisions amongst plant workers to introduce narrower and more flexible technician grades within a flatter structure which was one of their central justification for their 'single status' which precipitated the end of collective bargaining. A dilemma for the TGWU, the majority union within $\mathrm{BP}$, was that they were actively campaigning for single status within the chemical industry [23]. Secondly, in the very process of re-grading on this scale, it raises the potential for numerous local disputes and individual grievances over the process and its outcome. The agreement, for instance, says nothing on career progression through the scale. Within this particular context, which remains within the context of collective bargaining, the outcome of agreement is likely to depend on the relative strength of local trade union organisation. The central point is that trade union derecognition does not happen in isolation from other reforms within the employment relationship, but, almost by definition, it is integral to the introduction of new working practices which often involve job losses which can offer opportunity for at least some of the remaining workforce to receive relatively large increases in pay. However this also means formally or informally an intensification of work through job expansion. Pecuniary advantage can be offered in exchange for a loss of voice in the new working practices and employment relationship.

\section{Members attitudes to Personal Contracts}

This section draws on a survey of professional and managerial employees who have remained trade union members, with past experience of their pay and conditions determined by collective bargaining, who have moved to personal contracts of employment. It attempts to indicate the voice that they want, their reasons for trade union membership, and attitude towards personal contracts. Out of a total of around two thousand members who where identified transferring to personal contracts a sample of two hundred where surveyed following a number of lengthy, more informal interviews [for full details see 24]. Previous research, carried out on members of the same union, had indicated that there was a reluctance to move from collective bargaining to personal contracts [25]. Originally the sample had opposition to, even outright hostility, to personal contracts. There was a mixed yet balanced response to how the experience of personal contract was viewed by the individual. The larger number said that they had not changed their attitude whereas more than a fifth claimed that they had. For the group who now felt positive about their experience there was a feeling of greater security, more pay and bonuses, and further benefits. But there was some sensitivity to their privileged position as 
against non-managerial grades who might be exploited by a move to personal contracts. This still indicates some anxiety concerning personal contracts in comparison to collective bargaining with a recognition of relative power within the employment relationship.

Negatively they pointed to the lack of transparency in the pay scale and the determination of annual pay rise - or the lack of one. Overall the positive outweighed the negative responses by a ratio of about two to one.

Overall the majority felt more able, under personal contracts, to influence the outcome of the bargaining process. There appeared a feeling that the whole process of agreeing individual targets through merit, performance, or incentive bonus schemes, did lend itself to leaving the individual feeling more firmly in the driving seat. Some of the earlier negative comments do suggest, however, that this premise is by no means commonplace. Only a minority felt that they had fared worse than others in the workplace who maybe were covered by a collective agreement. This result can be interpreted in one of two ways, it can either be taken to illustrate the perceived benefits that can derive from being on a personal contract or alternatively can be taken as an indictment of collective bargaining. It is worthy of note that if a situation exists where a certain group remains covered by collective bargaining within a company then there is some transparency or even a reference point and therefore some comparison can be made. There are fears expressed later that in the event of the entire workplace going on to personal contract then such comparisons cannot be made but even more importantly the "feel good" factor i.e. that you are doing "better than the rest" is removed. When asked, even with the prospect of a legal right to collective bargaining, a majority would prefer to remain on personal contracts. Despite this it is important to note that these were all trade union members and had all maintained membership throughout the transition to personal contracts.

In rejecting traditional collective bargaining it is clear that this sample required the continuance of collective representation. A discernible theme that runs throughout the comments is a desire to retain some resemblance of collectivity within the personal contract relationship. In particular was the desire to come together to share information and discuss issues of common interest, to feel that the union recognised their own peculiar service requirements as personal contract holders. When asked about their reason for remaining within a trade union respondents 
ranked the availability of support and advice within the employment relationship high and ranked the financial and insurance services low. These are wider issues which need to be actively addressed by trade unions.

\section{A Framework for Collective Relations and Pay Determination}

The construction of personal contracts, and the unilateral determination of performance related pay, have been constructed out of a management agenda which has been integral to the shift in the frontier of control towards managerial prerogative. We have attempted to map the ground lost to unions through derecognition and particularly where this has involved a move to personal contracts. There is an assumption in both TUC and Labour policy documents that a reinstatement of the institutions of collective bargaining will be automatic in such circumstances. However, it is also clear that a while a call for a defense of traditional collective bargaining has been popular with trade unions it is not a strategy which is likely to mobilize popular support even amongst union members. Amongst our sample there had been a notable accommodation with personal contracts and who had no ambition to move back to collective bargaining to determine their pay and conditions. This mirrors the opinions of the personnel practitioners in Woods study [6]. Admittedly our survey was restricted to professional and managerial staff but it must be noted that they now constitute the largest single sector within trade union membership [26] and have been subject to the pressures of substantial changes in their working environment and conditions. Without an active campaign extolling the virtues of a move back to collective determination of the employment contract will there be a ground-swell of enthusiasm for a return to traditional collective bargaining even where union membership has remained.

This is not to argue for a withdrawal of trade unions from the collective arena into the provision of individual services to members. There is now enough experience from personal contracts, and some practice in collective agreements, to identify a framework for the reorientation, a new form, of collective bargaining. The emergence of flexible working along with personal contracts are clearly incompatible with bargaining which is premised on fragmented job demarcations with pay scales. It is also worth pointing to the comparison with those still dependent on collective 
bargaining as the comparator for many of our sample. Our research does indicate a range of issues amongst personal contract holders needing the collective and individual engagement of trade unions as membership organisations offering particular expertise in negotiating the employment relationship.

An important problem is that, with the current unitarist orthodoxy amongst management, the withdrawal from engagement with trade unions is seen as a means of eradicating conflict. In the process trade unions become identified as an outside party and not as a representative body with their employees as members; a membership progressively seen as a challenge to commitment to their employer. At the same time changes in working practices and employment relations are funded by 'downsizing'. Challenge to managerial prerogative becomes a symptom of lack of commitment and exercising a right to a voice at work is lost. But our research indicates that there are still considerable anxieties concerning the opacity of personal contracts, payment systems, and managerial prerogative. By definition within performance related pay systems which assesses differential reward for individuals holding comparable jobs some will be winners and some losers often for no apparent reason.

The new single status agreement in the public sector give some indication, along with others like that at United Utilities settled after a threat of derecognition and of retaliatory industrial action, of the areas for collective engagement. Likewise the very areas identified by the survey of trade union members, accommodated to the transfer to personal contract but anxious at the determination of their pay and conditions.

First, in derecognised workplaces, management have complete autonomy in determining the global level of the pay bill. Shifting from the normal parameters of arguing the difference between the cost of living against what an enterprise can afford, breaking out, they are able to unilaterally determine what is affordable denying fundamental transparency to the payment system. Transparency, and joint agreement, is also absent in the procedures for determining the criteria for individual performance and the measure of reward in pay review. Beyond this, and agreed in many partial derecognitions, is a union representation in grievances, discipline and a role in monitoring health and safety, and equal opportunities. A new collective relationship can be forged around broad determination of the terms and conditions within 'personal contact' with 
representation rights for individual members. However such a scenario requires both a revitalization, and protection, of workplace representatives.

1 [4]Building Prosperity - Flexibility, Efficiency and Fairness at Work Labour Party (nd) p. 5, see also The Labour Party - Road to the Manifesto, although this commitment was not referred to directly in the manifesto.

2 see e.g. [8], the earlier position of the TGWU, in rejecting new management approaches, such as quality circles, as a means of bye-passing trade unions as a means of communication, finds some vindication in the attitudes of Personnel managers reported in the IPD Focus Groups [6].

3 This paper is informed by research into 'culture change' and employment relations carried out by one of the authors at the three main BP chemical sites and the sites of a number of other companies in the industry.

$4 \quad$ Department of Employment 1992: para 1.15 cited in [19 p. 190]

$5 \quad$ The Personnel managers in Wood's sample indicate health and safety, equal opportunities and, more tenuously, communication pay deals with employees as the remaining important contribution of trade unions within the work place [6]. 


\section{References:}

1. Smith, P. and G. Morton, Union Exclusion and the Decollectivisation of Industrial Relations in Contemporary Britain. British Journal of Industrial Relations, 1993. Vol. 31. No. 2.

2. Smith, P. and G. Morton, Union Exclusion in Britain: Next Steps. Industrial Relations Journal, 1994. Vol. . No. .

3. Goodrich, C.L., The Frontier of Control: A Study in British Workshop Politics. 1975, London: Pluto Press. 284.

4. Labour, Building Prosperity: Flexibility, Efficiency and Fairness at Work, . nd (1996), The Labour Party: London.

5. TUC, Your Voice at Work, . 1995, Trade Union Congress: London.

6. Wood, S., Statutory Union Recognition, . 1997, Institute of Personnel and Development: London.

7. TGWU, Employee Involvement and Quality Circles. Policy Booklet. 1989, London: Transport \& General Workers Union.

8. Lucio, M.M. and S. Weston, The politics and complexity of trade union responses to new management practices. Human Resource Management Journal, 1992. Vol. 2. No. 4: pp. 77-.

9. Claydon, T., Union Derecognition in Britain in the 1980s. BJIR, 1989. Vol. 27. No. 2: pp. 214 - 224.

10. Claydon, T., Union Derecognition: A Re-examination, in Contemorary Industrial Relations: A Critical Analysis, I.J. Beardwell, Editor. 1996, Oxford University Press: Oxford. pp. 151 - 174.

11. Gall, G. and S. McKay, Recognition and Derecognition - the current situation, . 1996, Labour Research Department: London.

12. Millward, N., et al., Workplace Industrial Relations in Transition: The ED/ESRC/PSI/ACAS Surveys. 1992, Aldershot: Dartmouth. 395.

13. Bain, G.S., The Growth of White-Collar Unionism. 1970, Oxford: Oxford University Press. 233.

14. TGWU, Appendix 3: Supplementary submission on union recognition and collective bargaining rights (Companies in the Oil Industry) from TGWU National Secretary (Chemical, Oil and Rubber Group), in The Future of Trade Unions, E. Committee, Editor. 1994, HMSO: London. pp. 195-198.

15. TUC, Trade Union Trends, . 1996, a report for the TUC prepared by the Labour Research Department: London.

16. Billot, H., Business alloys, in People Management. 1996. pp. 38-42.

17. TGWU, B.C.L.-H.W.a., . Local Representation Agreement.

18. Flanders, A., Collective Bargaining: Prescriptions for Change, in Management and Unions: The Theory and Reform of Industrial Relations, A. Flanders, Editor. 1970, Faber \& Faber: London. pp. 155 -221.

19. Brown, W., The Contraction of Collective Bargaining in Britain. BJIR, 1993. Vol. 31. No. 2: pp. 189 - 200.

20. GMB, TGWU, and UNISON, . Single Status in Local Government.

21. TGWU, Human Resource Management, . 1993, Transport and General Workers Union: London.

22. TUC, human resource management: a trade union response, . 1994, Trade Union Congress: London.

23. TGWU, The Time has come for Equality of Opportunity for all Shell UK Employees, . nd, Transport and General Workers Union.

24. Finnerty, C., Personal Con-Tricks a Fix or Fad? A Study of the Attitude of Trade Unionists with Personal Contracts as a Means of Determining their Employment Relationship, in Human Resource Management. 1996, Nottingham Trent: Nottingham.

25. Evans, S. and M. Hudson, Standardised packages individually wrapped - A study of the introduction and operation of personal contracts in the port transport and electricity supply industries, . 1993, IRRU.

26. TUC, Professional and managerial staffs - trends and prospects, . 1997, Trade Union Congress: London. 